\title{
Nitrogen fertilization sources and insecticidal activity of aqueous seeds extract of Carica papaya against Spodoptera frugiperda in maize
}

\section{Rodolfo Figueroa-Brito ${ }^{1,3}$, Patricia Villa-Ayala1 ${ }^{1}$, Jesús F. López-Olguín², Arturo}

Huerta-de la Peña ${ }^{3}$, Juan R. Pacheco-Aguilar ${ }^{4}$, and Miguel A. Ramos-López ${ }^{4}$

${ }^{1}$ Centro de Desarrollo de Productos Bióticos. Instituto Politécnico Nacional. Carretera Yautepec-Jojutla, km

6, Calle Ceprobi No. 6, San Isidro, Yautepec, C.P. 62731, Morelos, Mexico.

${ }^{2}$ Centro de Agroecología y Posgrado MasAgro, Instituto de Ciencias, Benemérita Universidad Autónoma de Puebla. 14 Sur 6301, Ciudad Universitaria, 72570, Puebla, Mexico.

${ }^{3}$ Colegio de Postgraduados. Campus Puebla. Carretera Federal México-Puebla, km 125.5, Santiago Momoxpan, San Pedro Cholula, Puebla. 72760. Mexico.

${ }^{4}$ Facultad de Química, Universidad Autónoma de Querétaro. Cerro de las Campanas s/n, Col. Las Campanas, C.P. 76010, Santiago de Querétaro, Querétaro, Mexico.

\begin{abstract}
R. Figueroa-Brito, P. Villa-Ayala, J.F. López-Olguín, A. Huerta-de la Peña, J.R. PachecoAguilar, and M.A. Ramos-López. 2013. Nitrogen fertilization sources and insecticidal activity of aqueous seeds extract of Carica papaya against Spodoptera frugiperda in maize. Cien. Inv. Agr. 40(3): 567-577. The damage caused by the fall armyworm Spodoptera frugiperda Smith (Lepidoptera: Noctuidae) to vegetative-stage maize cultivated with chemical nitrogen fertilizers, vermicompost, and Carica papaya L. (Caricaceae) seed extract was estimated. Each shoot was infested with one first instar larva of S. frugiperda. The variables measured included the percentage of germination, length of the second and fifth leaves, stem diameter and plant height, and the estimation of damage caused by $S$. frugiperda larvae on maize. The results indicated that vermicompost helped seed germination on a relation 3:1 from black soil and vermicompost, the emergence was $100 \%$, while the emergence with black soil was $80 \%$. The ammonium sulfate increased the length of the second and fifth leaves $89.6 \%$ and $160.4 \%$ respectively, augmented the stem diameter and the plant height $290.2 \%$ and $13.3 \%$ respectively, respect to water treatment. The exogenous nitrogen sources stimulate $S$. frugiperda to cause more damage to the plant, the treatment urea showed $70 \%$ of damage, with phosphonitrate $62.3 \%$ and with ammonium sulfate $51.8 \%$, when were evaluated without aqueous seed extract of $C$. papaya. Ammonium sulfate + aqueous extract of $C$. papaya seeds showed the lowest insect damage to maize with $29.6 \%$.
\end{abstract}

Key words: Aqueous extract, Caricaceae, chemical fertilizers, damage, fall armyworm, Spodoptera frugiperda.

\section{Introduction}

Maize Zea mays L. (Poaceae) is a cereal crop adapted for various ecological conditions; it represents the cereal crop with the highest pro-

Received November 6, 2012. Accepted September 27, 2013. Corresponding author: agromyke@yahoo.com duction worldwide, with 867.5 million tons being produced in 2011 (USDA, 2011). In Mexico, the total surface cultivated with maize was 6.866 million ha in 2011, and the total production in 2011 was estimated to be 20.256 million tons (SAGARPA, 2011). However, this production is insufficient to satisfy the national demand; consequently, it is 
necessary to import it. Pests and diseases reduce the quality and yield of maize, and the excessive use of inorganic fertilizers (i.e. nitrogen fertilization) causes nutritional deficiencies and decreased pest resistance (Díez et al., 2000).

The fall armyworm Spodoptera frugiperda Smith (Lepidoptera: Noctuidae) is the principal insect pest for maize, because it attacks during all developmental stages. In Mexico, this insect causes crop losses between 20-100\% (Del Rincón et al., 2006). The principal damage occurs in the initial developmental stage of the plant, 30 days after sowing, when the insect feeds off the leaves and shoots, especially in the meristem.

Improved soil fertility could cause some plants to become more susceptible to certain insects (Nicholls and Altieri, 2008). Van Dusen (1988) demonstrated that high rates of nitrogen fertilization cause an increase of $S$. frugiperda infection when compared to other insect pest populations. Additionally, the low abundance of insect herbivores on organic crops has been attributed to low plant nitrogen content (Jahn et al., 2005; Birkhofer et al., 2008; Altieri et al., 2012; Jactel et al., 2012; Rusch et al., 2013). Phelan et al. (1995) demonstrated that, under greenhouse conditions, females of Ostrinia nubilalis Hübner (Lepidoptera: Pyralidae) oviposited significantly more eggs in maize plants cultivated with chemical fertilizers nitrogenous than in plants cultivated with organic soils with manure cow. These results demonstrate that soil fertilizer management can affect plant quality, which, in turn, can affect insect pest abundance and consequent levels of damage (Brévault et al., 2007; De Groote et al., 2010; Ratnadass et al., 2012).

Many practices have been implemented to control $S$. frugiperda infestations; the most utilized practice has been the application of organo-

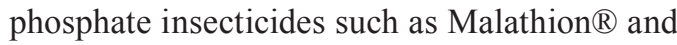
Parathion-methyl ${ }^{\circledR}$, which are dangerous to the farmer's health (De Liñán, 2009). Alternatively, seven applications every eight days of extract from leaves of Azadirachta indica A. Juss. (Meliaceae) or Gliricidia sepium Kunth (Fabaceae) $\left(5 \mathrm{~mL} \mathrm{~L}^{-1}\right)$, reduces the damage from insect pest and also increases maize production in 37.6 and $35.8 \%$ with G. sepium and A. indica respectively (Montes-Molina et al., 2008). Additionally, the application of powder of Mamey, Maradol, Amarilla and Hawaiana varieties from Carica papaya L. (Caricaeae) at 15 or $10 \%$, in artificial diet, demonstrated mortality of $90 \%$ with all varieties at $15 \%$ after $72 \mathrm{~h}$ and the same mortality with Mamey, Maradol and Amarilla varieties after $96 \mathrm{~h}$ at 10\% (Franco et al., 2006).

The use of chemical fertilizers nitrogenous strengthens maize plant vigor, but these plants become more "desirable" to insect pests such as S. frugiperda (Rusch et al., 2013). The synthetic insecticides used in the control of this insect pest could be dangerous to the environment and to human health; alternatively, the use of organic fertilization and/or botanic insecticides improves soil fertility, reduces maize damage, and increases production (Montes-Molina et al., 2008; Ratnadass et al., 2012).

This aim of this study was evaluate the effect of fertilizer organic or nitrogenous and the application of C. papaya aqueous extract on the mortality $S$. frugiperda larvae and estimate the damage of maize plants grown under greenhouse conditions.

\section{Materials and methods}

\section{Rearing of S. frugiperda}

In July 2005, 153 S. frugiperda larvae of different instars were collected from maize crops in Yautepec, State of Morelos, Mexico, located on the geographic coordinates $18^{\circ} 53^{\prime} \mathrm{N}$ latitude and $99^{\circ} 04^{\prime} \mathrm{W}$ longitude, at altitude of 1210 meters above sea level. The larvae were collected from the meristems of plants 15 days post-seeding. The 
larvae were reared with an artificial diet (Burton and Perkins, 1987) in the Entomology Laboratory of Centro de Desarrollo de Productos Bióticos, Instituto Politécnico Nacional, Yautepec, Morelos. The insects were individually deposited in plastic glasses ( $3 \mathrm{~cm}$ height and $3.5 \mathrm{~cm}$ diameter) with toppers. The larvae passed to the pupal stage in the same glasses. When the adults emerged, they were placed in waxed paper bags containing one plastic Petri dish of $10 \mathrm{~cm}$ diameter with cotton moistened with a $10 \%$ sugar solution. These adults mated with each other randomly. The $\mathrm{F}_{2}$ larvae were used in the bioassay.

\section{Seed extract of C. papaya}

Fruits of C. papaya Maradol were allowed to dry in shade for 15 days at room temperature $\left(28^{\circ} \mathrm{C} \pm 5\right)$, after which then they were crushed using an electric mill (model MF 10 Basic, 1KAWerke GMBH and Co. Germany) with a mesh of $0.25 \mathrm{~mm}$. Twenty grams of the seed powder was deposited in an Erlenmeyer flask with $1 \mathrm{~L}$ of distilled water to be macerated for $12 \mathrm{~h}$ at room temperature. The mix was then filtered using sterile filtered paper (Whatman ${ }^{\circledR}$ No. 5), and the solution was used immediately in the bioassay at $20 \%$, we increase $5 \%$ over the concentration of papaya seed extract of the insecticidal activity reported by Franco et al. (2006) who mixed with artificial diet on S. frugiperda.

\section{Substrates and maize seeds}

The maize seed used was of the "San Juan" variety provided by corn producers San Juan Atenco, Puebla. The substrates utilized were black soil and vermicompost of Momoxpan, Puebla. The black soil was sandy loam, $\mathrm{pH}(6.5)$, organic matter (0.59\%), and macronutrients and micronutrients $\left(\mathrm{mg} \mathrm{kg}^{-1}\right)$ : nitrate $\left(\mathrm{N}-\mathrm{NO}_{3} 2.01\right)$, phosphorus (15.4), potassium (139), calcium (495.62) and magnesium (88.36) as sodium (23.74), iron (16.79), copper (0.96) and boron (0.24), respectively.
The vermicompost was produced with vegetable waste and agricultural waste collected from nearby local market and agricultural farm. Agricultural wastes mainly include straw, dry leaves of crop plants, weeds while vegetable wastes include unused, rotten vegetable parts. Vermicomposting was carried out as worm bin $(100 \times 100 \times 120$ $\mathrm{cm})$. After partial decomposition of waste in pit, main species of earthworm Lumbricus terrestris L. (100 individuals per pit, worm bin) were released. The process of vermicomposting was followed as described by Kumar and Raheman (2012). Finally, well-ferment vermicompost was obtained. The uniformly mixed samples (100 g) of all manures were collected immediately from the pits for nutrients analysis.

The vermicompost a $\mathrm{pH}$ (9.49), organic matter (46.34\%) and macronutrients and micronutrients $\left(\mathrm{mg} \mathrm{kg}^{-1}\right)$ : total nitrogen $(1.65 \%)$, nitrate $\left(\mathrm{N}^{-\mathrm{NO}_{3}}\right.$ $\left.502.53 \mathrm{mg} \mathrm{kg}^{-1}\right)$, phosphorus $(0.39 \%)$, potassium (2.31\%), calcium $(2.82 \%)$ and magnesium $(0.62 \%)$ as sodium (23.74\%), iron (6213.3 $\left.\mathrm{mg} \mathrm{kg}^{-1}\right)$, copper (39.78 $\left.\mathrm{mg} \mathrm{kg}^{-1}\right)$, boron $\left(36.23 \mathrm{mg} \mathrm{kg}^{-1}\right)$ and zinc (112.79 $\mathrm{mg} \mathrm{kg}^{-1}$ ).

\section{Bioassay}

Some plastic bags $(33 \times 33 \mathrm{~cm})$ were filled with $6 \mathrm{~kg}$ of black soil and others with black soil and vermicompost (3:1 w/w) according to Kumar and Raheman (2012). Two seeds were planted in each bag. After 20 days, one of the two maize plants was manually removed of each bag and fertilizers were added (ammonium sulfate $13.6 \mathrm{~g} \mathrm{bag}^{-1}$; urea $6 \mathrm{~g} \mathrm{bag}^{-1}$; phosphonitrate $6.56 \mathrm{~g} \mathrm{bag}^{-1}$ ) with $50 \%$ of the $\mathrm{N}$, all added when the plants were in phase $\mathrm{V} 8$, i.e. the vegetative phase when the plants have eight leaves (López et al., 1999).

The following treatments were evaluated: 1) black soil (BS) + ammonium sulfate (AS); 2) BS + AS + aqueous extract of C. papaya seeds at $20 \mathrm{~g} \mathrm{~L}^{-1}$ (AECPS) was applied to the foliage six rows of five maize plants, i.e. a total of 30 plants, with a 
hand pump as in normal agricultural practices; 3 ) $\mathrm{BS}+$ vermicompost (VE); 4) BS + VE + AECPS; 5) $\mathrm{BS}+$ urea (U); 6) BS + U + AECPS; 7) BS + phosphonitrate (PN); 8) BS + PN + AECPS; as positive controls: 9) BS + AECPS; 10) BS + Malathion $^{\circledR}(2 \mu \mathrm{L} / 14 \mathrm{~mL})$, and as a negative control: 11) BS. Treatments were distributed randomly, with six repetition per treatment and five plants per repetition.

After 3 h of sprayed the C. papaya seeds extract, the meristem from all plants were infested with one first instar larva of $S$. frugiperda using a fine brush. The variables measured included the following: rate of emergence (two weeks after planting), length of the second and fifth leaves, stem (diameter), and plant height from the soil surface to the inclusion of the last leaf. The damage by $S$. frugiperda larvae was estimated with valuation scale using by Mihn (1984), to S. frugiperda with a nine-level scale. The calculating from incidence and severity of the damage was the average of the estimated damage of 30 plants per treatment.

\section{Statistical analysis}

Data were assessed for normality and homoscedasticity prior to analysis. An analysis of variance and orthogonal analysis were used followed by a comparison using the Tukey test. In some cases Kruskal-Wallis non-parametric analysis of variance was used when data violated these assumptions and could not be corrected using a transformation (SAS INSTITUTE, 2002. SAS System for Windows, release 9.0. SAS Institute, Cary, NC, USA).

\section{Results}

\section{Emergence percentage}

The emergence of the "San Juan" variety of maize was significantly different between BS + VE (3:1) (100\% emergence) and BS alone (80\% emergence) ( $\mathrm{P} \leq 0.0001$, Figure 1); consequently, it was necessary to replant BS treatments to obtain $100 \%$ emergence.

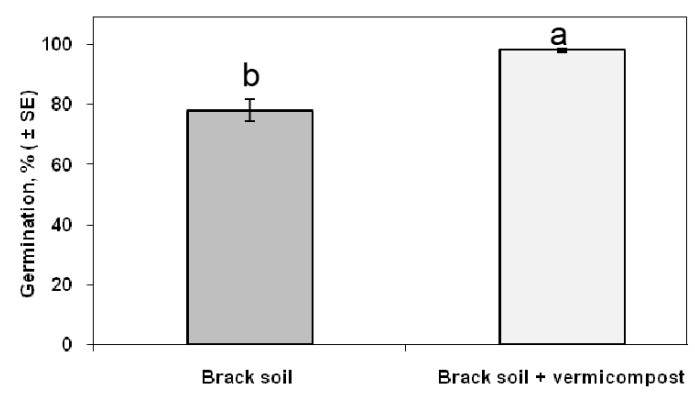

Figure 1. Percentage of emergence of maize var."San Juan" with black soil and black soil + vermicompost.

\section{Length of the second and fifth leaves}

The effect of different treatments on the length of the second leaf was significant $(\mathrm{P} \leq 0.0001)$. The mean differences in the orthogonal test occurred by the type of fertilization $(\mathrm{P} \leq 0.0001)$ and the interaction between fertilization and papaya extract application $(\mathrm{P}=0.0040)$. The maize plants fertilized with AS showed the largest second leaves $(94.8 \mathrm{~cm})$. This effect was higher in the treatment AS + AECPS (106 cm) (Table 1).

Similar results were observed for the fifth maize leaf, where the mean differences in the orthogonal test were significant according the type of fertilization $(\mathrm{P} \leq 0.0001)$ and the papaya extract application $(\mathrm{P} \leq 0.0001)$. The AS or AS + AECPS treatments were more significant, with leaf length increases of 144 and $152 \mathrm{~cm}$, respectively (Table 1).

\section{Diameter of stem and height of maize plants}

The effects of different treatments on the diameter of the stem differed significantly $(\mathrm{P} \leq 0.0001)$ (Table 1) with fertilization type $(P \leq 0.0001)$ and papaya extract application $(\mathrm{P} \leq 0.0229)$. The AS and AS + AECPS treatments had the most significant effects, with diameter of stems of $23.8 \mathrm{~mm}$ and $25.1 \mathrm{~mm}$ diameter, respectively, who were statistically equal to the PN + AECPS and U + AECPS 
Table 1. Leaf length, stem diameter and height of maize treated with chemical or organic fertilization, with or without aqueous extract of C. papaya seeds.

\begin{tabular}{|c|c|c|c|c|}
\hline \multirow[b]{2}{*}{ Treatment } & \multicolumn{2}{|c|}{ Length $(\mathrm{cm})$} & \multirow{2}{*}{$\begin{array}{l}\text { Diameter }(\mathrm{mm}) \\
\text { Stem }\end{array}$} & \multirow{2}{*}{$\begin{array}{c}\text { Height }(\mathrm{m}) \\
\text { Plant }\end{array}$} \\
\hline & Leaf 2 & Leaf 5 & & \\
\hline Ammonium Sulfate & $94.8 \pm 3.2 \mathrm{~b}$ & $144.0 \pm 3.7 \mathrm{ab}$ & $23.8 \pm 3.6 \mathrm{ab}$ & $1.7 \pm 0.3 \mathrm{ab}$ \\
\hline Ammonium Sulfate + Extract $^{1}$ & $106.0 \pm 5.1 \mathrm{a}$ & $152.0 \pm 6.1 \mathrm{a}$ & $25.1 \pm 2.5 \mathrm{a}$ & $2.2 \pm 0.3 \mathrm{a}$ \\
\hline Urea & $76.3 \pm 3.4 \mathrm{c}$ & $90.1 \pm 3.9 \mathrm{de}$ & $19.5 \pm 1.6 \mathrm{bc}$ & $1.4 \pm 0.2 \mathrm{bc}$ \\
\hline Urea + Extract $^{1}$ & $78.6 \pm 6.5 \mathrm{c}$ & $96.1 \pm 6.0 \mathrm{~d}$ & $21.5 \pm 3.6 \mathrm{abc}$ & $1.6 \pm 0.3 \mathrm{ab}$ \\
\hline Phosphonitrate & $70.1 \pm 5.6 \mathrm{~cd}$ & $125.6 \pm 3.2 \mathrm{c}$ & $18.0 \pm 3.1 \mathrm{~cd}$ & $1.5 \pm 0.2 \mathrm{bc}$ \\
\hline Phosphonitrate + Extract $^{1}$ & $76.6 \pm 5.1 \mathrm{c}$ & $134.8 \pm 3.2 \mathrm{bc}$ & $23.2 \pm 2.3 \mathrm{abc}$ & $1.6 \pm 0.3 \mathrm{ab}$ \\
\hline Vermicompost & $70.1 \pm 2.2 \mathrm{~cd}$ & $84.8 \pm 6.5 \mathrm{e}$ & $7.5 \pm 2.8 \mathrm{ef}$ & $1.3 \pm 0.2 \mathrm{bc}$ \\
\hline Vermicompost + Extract $^{1}$ & $69.0 \pm 4.1 \mathrm{~cd}$ & $90.0 \pm 4.1 \mathrm{de}$ & $8.3 \pm 3.1 \mathrm{ef}$ & $1.5 \pm 0.3 \mathrm{bc}$ \\
\hline Control Water & $50.0 \pm 5.7 \mathrm{e}$ & $55.3 \pm 4.6 \mathrm{f}$ & $6.1 \pm 2.3 \mathrm{f}$ & $0.9 \pm 0.1 \mathrm{c}$ \\
\hline Control Extract ${ }^{1}$ & $55.1 \pm 9.3 \mathrm{e}$ & $58.1 \pm 7.3 \mathrm{f}$ & $10.3 \pm 2.3 \mathrm{ef}$ & $0.9 \pm 0.2 \mathrm{c}$ \\
\hline Control Malathion & $60.0 \pm 4.9 \mathrm{de}$ & $63.1 \pm 8.8 \mathrm{f}$ & $12.8 \pm 2.1 \mathrm{de}$ & $1.3 \pm 0.4 \mathrm{bc}$ \\
\hline
\end{tabular}

${ }^{1}$ Extract $=$ aqueous extract of $C$. papaya seeds; Means $( \pm \mathrm{SE})$ with a different letter in a column represent significant differences between treatments (Tukey's test, $\mathrm{P} \leq 0.05$ ).

treatments who also stimulated diameter stem (23.2 and $21.5 \mathrm{~mm}$, respectively). The diameter stems of plants treated with VE and VE + AECPS were significantly equal to that of the controls.

In relation to plant height, the effects of the treatments were significant between fertilization types $(\mathrm{P} \leq 0.0001)$ and papaya extract application $(\mathrm{P}=0.0106)$. The AS + AECPS and AS treatments induced maize plant growth of 2.2 and $1.7 \mathrm{~m}$, respectively. The U + AECPS and PN + AECPS treatments were also increased the height of the corn plant (1.6 m, Table 1).

\section{Damage to maize plants from S. frugiperda}

The effect of the treatments on damage estimation was significant by fertilization type $(\mathrm{P} \leq 0.0001)$, papaya extract application $(\mathrm{P} \leq 0.0001)$, and interaction between fertilizer and papaya extract application $(\mathrm{P} \leq 0.0001)$ (Table 2$)$.

The $S$. frugiperda larvae cause more damage to maize plants fertilized with $\mathrm{U}, \mathrm{PN}$, and AS, causing $70,62.3$, and $51.8 \%$ damage, respectively. Moreover, plants treated with VE presented less damage (32.3\%) (Table 2).
Table 2. Damage of Spodoptera frugiperda larvae in maize.

\begin{tabular}{lcc}
\hline & \multicolumn{2}{c}{ Damage (\%) } \\
\cline { 2 - 3 } Treatment & Without extract & With extract \\
\hline Urea & $70.0 \mathrm{a}$ & $56.6 \mathrm{c}$ \\
Phosphonitrate & $62.3 \mathrm{~b}$ & $35.1 \mathrm{e}$ \\
Ammonium & $51.8 \mathrm{c}$ & $29.6 \mathrm{f}$ \\
Sulfate & $32.3 \mathrm{ef}$ & $31.1 \mathrm{ef}$ \\
Vermicompost & $46.3 \mathrm{~d}$ & - \\
Control Water & - & $11.6 \mathrm{~g}$ \\
Control Extract & $8.6 \mathrm{~g}$ & - \\
Control Malathion &
\end{tabular}

Means ( \pm SE) with different letters represent significant differences between treatments (Tukey's test, $\mathrm{P} \leq 0.05$ ).

All treatments (except vermicompost) that included the aqueous extract of $C$. papaya seeds inhibited damage caused by $S$. frugiperda larvae (VE + AECPS except), the most evident being AS + AECPS (29.6\%), followed by VE + AECPS and PN + AECPS treatments (31.1 and 35.1\%, respectively). In plants treated with $\mathrm{U}+\mathrm{AECPS}$, the damage was $56.6 \%$. However, in the positive control treatments with BS + Malathion ${ }^{\circledR}$ and BS + AECPS, insects caused 8.6 and $11.6 \%$ damage, respectively. 


\section{Discussion}

In this research, the use of vermicompost stimulated the emergence of maize seeds; this improvement resulted in better initial growth of the plants. Moreover, with sowing in black soil, it became necessary to reseed to increase emergence rates. A study by Sinha et al. (2010) determined that vermicompost improved plant growth, color, and brightness of the leaves in maize, wheat, and tomato. There were also fewer incidences of pests and diseases and a reduction in water demand on tomato and maize plants, thus significantly reducing the need for chemical pesticides.

Nitrogen fertilization increased diameter of stem of corn plants when compared with plants grown in vermicompost. Ammonium sulfate was the nitrogen fertilizer with the greatest ability to increase the length leaves, diameter stems and height of maize plants. Phosphonitrate and urea stimulated diameter stem. Residual effects of $\mathrm{N}$ or $\mathrm{P}$ based manure or compost application increased the biomass and crop production for one year and influenced soil properties for several years. Also the residual effects of manure and compost applications significantly increased soil electrical conductivity and $\mathrm{pH}$ levels and plant-available $\mathrm{P}$. In the present study the vermicompost contained nitrogen, phosphorus and electrical conductivity in the range of composted cow for good growth of corn, except that the $\mathrm{pH}$ was slightly elevated. With the application of the biomass was formed vermicompost of corn plants (except diameter stem) similar to the biomass of the corn plants with chemical fertilizers urea and phosphorus, however the application of ammonium sulfate growing maize plants was better.

Farmers in Patzun, Guatemala changed from organic fertilizers ("postura" of combining any available materials: ashes, lime, crop residues, weeds, and manure from goats, cows, horses, rabbits, and chickens in a mulch pile or well cow manure) by urea but observed the negative consequences of this change, with an increase in insect pests in the maize crops (Morales et al., 2001).

Some studies demonstrate that augmented nitrogen fertilizers increase populations of Frankliniella occidentalis Pergande (Thysanoptera: Thripidae) in tomato (Brodbeck et al., 2001), Aphis gossypii Glover (Hemiptera: Aphididae) in cotton (Nevo and Coll, 2001), Nilaparvata lugens Stål and Sogatella furcifera Horvath (Hemiptera: Delphacidae) in rice (Lu et al., 2007). Other researchers have shown that populations of Ostrinia nubilaris Hubner (Lepidoptera: Crambidae) (Phelan et al., 1995), Diabrotica virgifera LeConte (Coleoptera: Chrysomelidae) (Moeser and Vidal, 2004) and Peregrinus maidis Ashmead (Hemiptera: Delphacidae) (Wang et al., 2006), increased in maize when fertilized with nitrogen.

Moreover, the use of vermicompost reduces pest and disease incidences and also reduces water demand in maize and tomato crops. In the present study we observed less damage from the larvae of S. frugiperda and 'reduced demand of water' for irrigation in plants grown on vermicompost. Sinha et al. (2010) mentioned composts work as a 'slow-release fertilizer' whereas chemical fertilizers release their nutrients rather quickly in soil and soon get depleted. This corn plants develop in vermicompost are less "succulent and palatable" to insect pests, such as the larvae of $S$. frugiperda. The use of 20 or $40 \%$ vermicompost in tomato and cucumber grown under greenhouse conditions resulted in reduced damage by Acalymma vittatum F. and Diabrotica undecimpunctata Barber (Coleoptera: Chrysomelidae), and Manduca quinquemaculata Haworth (Lepidoptera: Sphingidae) (Yardim et al., 2006). In our study, maize plants that were developed with $25 \%$ of vermicompost under greenhouse conditions, had less damage caused by the larvae of $S$. frugiperda developed plants with chemical fertilizers urea, phosphonitrate or ammonium sulfate. The use of vermicompost water solutions (1:5) as aqueous extracts at 5, 10, and $20 \%$ sprayed on A. vittatum and Manduca sexta L. (Lepidoptera: Sphingidae) in cucumber 
and tomato suppressed the establishment and damage of both insect pests (Edwards et al., 2010). In this research, the use of aqueous extract from $C$. papaya seeds reduced $S$. frugiperda damage in maize plants fertilized with any nitrogen source except with vermicompost, where the damage was same with or without application of extract from C. papaya. Previous studies with C. papaya seeds demonstrated that powder, aqueous, and acetonic extracts, their fractions, and pure compounds exhibited activity against $S$. frugiperda larvae (Figueroa-Brito, 2002a, b; Franco et al., 2006).

The commercial botanical insecticides of neem have proved effective in protecting corn crop. With the application of these insecticides botanicals, the larvae $S$. frugiperda only caused minimal damage (Oleonim $80 \mathrm{CE}^{\circledR}$ and Oleonim $50 \mathrm{CE}^{\circledR}$ : 0.07 and 0.06 larvae/plant) or moderate (Neem oil extract ${ }^{\circledR}$ and Neem Azal-T/S ${ }^{\circledR}: 25.8-17.5 \%$ ) on maize plants (Pérez et al., 1997; Lima et al., 2008; Gutiérrez-García et al., 2010), while in our study $11.6 \%$ was the percentage of plant damage to corn treated aqueous extract of $C$. papaya.

Leaf extracts from $A$. indica and Gliricidia sepium Kunth (Fabaceae) $\left(5 \mathrm{~mL} \mathrm{~L}^{-1}\right)$ reduced damage rates in maize (18 and 23\%) (Montes-Molina et al., 2008), is significantly higher than the aqueous extract of C. papaya (11.6\%) of our study. These extracts reduced the emission of carbon dioxide $\left(\mathrm{CO}_{2}\right)$ in urea-amended soil and the emission of nitrous oxide $\left(\mathrm{N}_{2} \mathrm{O}\right)$ in unamended soil when incubated at $40 \%$ water holding capacity (Méndez-Bautista et al., 2009). The main fatty acid components of the C. papaya chloroformic seed extract were, oleic acid, palmitic acid, and stearic acid, these acids caused larval viability of $33.3,48.5$, and $62.5 \%$ when exposed to $1,600 \mathrm{ppm}$ respectively against S. frugiperda (Pérez-Gutiérrez et al., 2011), so the reduction in corn injury by the application of the aqueous extract of seeds of $C$. papaya may be due to the presence of these acids.

There are several studies analyzing the scope and impact of organic fertilizers in Latin America as agroecological technologies used by NOGs on maize farming systems, such as EPAGRI, ASPTA in Brazil, COAGRES in El Salvador (COAG, 2004), and ALTERTEC in Guatemala (Pretty, 1997). Phelan et al. (1995) mentioned that the adequate and prolonged management of organic matter in the soil could induce better resistance of the plants to insect pests. In this sense, the use of botanic products can help to reduce insect pests, diseases, and others problems in the soil (Altieri and Nicholls, 2000). Rao (2003) showed that application of manure, neem paste, and vermicompost reduced populations of $S$. litura and $H$. armigera in peanut when compared with chemical fertilizers. A similar effect happened in our study, with the application of vermicompost and seed extract of C. papaya decreased the percentage of corn damage caused by S. frugiperda compared with chemical nitrogen fertilizers. These studies showed that soil management fertilization affects plant susceptibility to insect pest attack. Crops that grow in soils with high organic matter content and high biological activity exhibit fewer pest incidences (Altieri et al., 2012). On the other hand, agricultural practices with excessive use of chemical fertilizers create nutrient imbalances and also reduce plant defense. A similar effect was observed in this study: maize plants with nitrogen fertilization grew more but with greater damage by $S$. frugiperda. In contrast, the incorporation of vermicompost increased the germination of maize seeds, and like the vermicompost + aqueous extract of $C$. papaya seeds reduced the damage of $S$. frugiperda in the maize plants grown with nitrogen fertilization by these damage was greater than one application aqueous extract $C$. papaya or Malathion, this is attributable to the larvae of $S$. frugiperda prefer to feed on green plants "succulent" developed corn nitrogen source that weak plants developed yellow and vermicompost. Altieri and Nicholls (2003) shows that the ability of a crop plant to resist or tolerate insect pests and diseases is tied to optimal physical, chemical and mainly biological properties of soils. Soils with high organic matter and active soil biology generally exhibit good soil fertility. Crops grown 
in such soils generally exhibit lower abundance of several insect herbivores, reductions that may be attributed to a lower nitrogen content in organically farmed crops.

There are some studies that reports phenolic compounds, extracted from vermicompost, which exhibit feeding deterrent activity against Helicoverpa armigera Hübner, Spodoptera exigua Hübner and Spodoptera litura Fabricius (Lepidoptera: Noctuidae) (Mahanil et al., 2008; Bhonwong et al., 2009). It might be probably that phenolic compounds had in our vemicompost and had deterrent activity against $S$. frugiperda so there are not significantly differences in treatments with or without vermicompost.

In this research, plants with vermicompost showed less development and less damage caused by $S$. frugiperda, that plants treated with nitrogen synthetic fertilizers, this insect pest showed a positive correlation with the nitrogen level, this result was similar with positive correlation between $S$. frugiperda and other crops (Diawara et al., 1991; Davidson and Potter, 1995). It may possible that S. frugiperda as other insect pest, prefer maize plants cultivated with chemical fertilizers, to find them more attractive and succulent.

The use of vermicompost with aqueous extract of C. papaya seeds can be recommended to be use in Agroecological Pest Management (APM) programs to improve crop development and control of $S$. frugiperda. In future experiments, those vermicompost phenolic compounds might be evaluated against $S$. frugiperda to identify potential feeding deterrent activity against this insect.

In this research, the results showed that vermicompost improved germination of the maize seeds, also the use of nitrogen fertilizers stimulated the damage caused by $S$. frugiperda, and ammonium sulfate induced the highest plant growth and development.

\section{Resumen}

R. Figueroa-Brito, P. Villa-Ayala, J.F. López-Olguín, A. Huerta-de la Peña, J.R. PachecoAguilar y M.A. Ramos-López. 2013. Fuentes nitrogenadas de fertilización y actividad insecticida del extracto acuoso de semilla de Carica papaya contra Spodoptera frugiperda en maíz. Cien. Inv. Agr. 40(3): 567-577. Se estimó el daño causado por el gusano cogollero del maíz Spodoptera frugiperda Smith (Lepidoptera: Noctuidae) durante la etapa vegetativa de maíz cultivado con fertilizantes nitrogenados químicos, vermicomposta, y extracto acuoso de semillas de Carica papaya L. (Caricaceae). Cada brote se infestó con una larva de primer instar de $S$. frugiperda. Las variables evaluadas incluyen el porcentaje de germinación. Las variables respuesta fueron el porcentaje de emergencia, longitud de la segunda y quinta hoja, diámetro de tallo y altura de la planta; así como la estimación de daño causado por larvas de $S$. frugiperda al maíz. Los resultados indicaron que la vermicomposta ayudó a la emergencia de la semilla, en una relación 3:1 de suelo con vermicomposta alcanzó 100\% de emergencia, mientras que solo con suelo, la emergencia fue de $80 \%$; el sulfato de amonio incrementó el tamaño de la segunda hoja y quinta hoja 89,6 y 160,4\% respectivamente, aumentó el diámetro de tallo y la altura de la planta 290,2 y 13,3\%, respecto al tratamiento donde solo se aplicó agua. Las fuentes de nitrógeno estimularon que $S$. frugiperda ocasionara más daño a la planta, el tratamiento con urea presentó $70 \%$ de daño, con fosfonitrato $62,3 \%$, con sulfato de amonio fue de $51,8 \%$ sin extracto acuoso de semillas de C. papaya. El tratamiento con sulfato de amonio + extracto acuoso de semillas de $C$. papaya registró el menor daño del insecto al maíz con 29,6\%.

Palabras clave: Caricaceae, daño, extracto acuoso, fertilizantes químicos, gusano cogollero. 


\section{References}

Altieri, S.M.A., and C.I. Nicholls. 2000. Bases agroecológicas para una agricultura sustentable. Agroecología. Teoría y práctica para una agricultura sustentable. Serie textos básicos para la formación ambiental. D. F. México. p. 13-45.

Altieri, S.M.A., and C.I. Nicholls. 2003. Soil fertility management and insects pests: harmonizing soil and plant health in agroecosystems. Soil and Tillage Research 72:203-211.

Altieri, S.M.A., L. Ponti, and C.I. Nicholls. 2012. Soil fertility biodiversity and pest management. p. 72-84. In: G.M. Gurr, S.D. Wratten, and W.E. Snyder (eds.). Biodiversity and insect pests: key issues for sustainable management. WileyBlackwell. Wiley \& Sons. UK.

Birkhofer, K., T.M. Bezemer, J. Bloem, M. Bonkowski, S. Christensen, D. Dubois, F. Ekelund, A. Fliebach, L. Gunst, K. Hedlund, P. Mäder, J. Mikola, C. Robin, H. Setälä, F. Tatin-Froux, W.H. Van der Putten, and S. Scheu. 2008. Long-term organic farming fosters below and aboveground biota: implications for soils quality, biological control and productivity. Soil Biology and Biochemistry 40:2297-2308.

Brévault, T., S. Bikay, Maldes J.M., and K. Naudin. 2007. Impact of a no-till with mulch soil management strategy on soil macrofauna communities I a cotton cropping system. Soil Tillage Research. 97:140-149.

Brodbeck, B., J. Stavisky, J. Funderburk, P. Andersen, and S. Olson. 2001. Flower nitrogen status and populations of Frankliniella occidentalis feeding on Lycopersicon esculentum. Entomologia Experimentalis et Applicata 99:165-172.

Bhonwong, A., M.J. Stout, J. Attajarusit, and P. Tantasawat. 2009. Defensive role of tomato polyphenol oxidases against collar bollworm (Helicoverpa armigera) and beet armyworm (Spodoptera exigua). Journal of Chemical Ecology 35:28-38.

Burton, L.R., and W.D. Perkins. 1987. Rearing the corn earworm and fall armyworm for maize resistance studies. Proceedings of the International Symposium on Methodologies for Developing Host Plant Resistance to Maize Insects. CIM-
MYT (International Maize and Wheat Improvement Center). Mexico. p. 35-37.

COAG - Council of Australian Governments. 2004. Ammonium nitrate, a compound commonly used as fertilizer, is being restricted due to its potential for illicit use as an explosive. Councils are encouraged to make themselves aware of the proposed new restrictions. New restriction on ammonium nitrate fertilizer-circular 8.2. Local Government Association of South Australia. Australia. Available online at: http://www.lga. sa.gov.au/_vti_bin/shtml.exe/public/maps/regional. htm/page.aspx $\mathrm{u}=234 \& \mathrm{c}=8294$ (Website accessed: October 25, 2013).

Davidson, A.W., and D.A. Potter. 1995. Response of plant-feeding, predatory, and soil-inhabiting invertebrates to Acremonium endophyte and nitrogen fertilization in tall fescue turf. Journal of Economic Entomology 88:367-379.

De Groote, H., B. Vanlauwe, E. Rutto, G.D. Odhiambo, F. Kanampiu, and Z.R. Khan. 2010. Economic analysis of different options in integrated pest and soil fertility management in maize systems of Western Kenya. Agricultural Economics 41:471-482.

De Liñán, C. 2009. Agroquímicos de México. Editorial Tecnoagrícola de México S. A. de C. V. D. F. México. p. 107-146.

Del Rincón C.M.C., J. Méndez, and E. Ibarra. 2006. Caracterización de cepas nativas de Bacillus thuringiensis con actividad insecticida hacia el gusano cogollero del maíz Spodoptera frugiperda (Lepidoptera: Noctuidae). Folia Entomológica Mexicana 45:157-164.

Diawara, M., N. Hill, B. Wiseman, and D. Eisenhower. 1991. Panicle-stage resistance to Spodoptera frugiperda (Lepidoptera: Noctuidae) in converted Sorghum accessions. Journal Economic Entomology 84:337-344.

Díez, J.A., R. Caballero, R. Román, A. Tanquis, C. Cartagena, and A. Vallego. 2000. Integrated fertilizer and irrigation management to reduce nitrate leaching in Central Spain. Journal of Environmental Quality 29:1539-1547.

Edwards, C.A., N.Q. Arancon, M. Vasko-Bennett, A. Askar, and G. Keeney. 2010. Effect of aque- 
ous extracts from vermicomposts on attacks by cucumber beetles (Acalymna vittatum) (Fabr.) on cucumbers and tobacco hornworm (Manduca sexta) (L.) on tomatoes. Pedobiologia 53:141148.

Figueroa-Brito, R., M. Camino, M.C. Pérez-Amador, V. Muñoz, E. Bratoeff, and C. Labastida. 2002a. Fatty acid composition and toxic activity of the acetonic extract of Carica papaya L. (Caricaceae) seeds. Phyton International Journal of Experimental Botany 69:97-99.

Figueroa-Brito, R., J.S. Calderón, M.C. Pérez-Amador, V. Muñoz, M.C. Hernández, M.E. Valdés, and L. Aldana. 2002b. Toxicity and growth inhibitory effects of extracts and some fractions from Carica papaya against Spodoptera frugiperda (Lepidoptera: Noctuidae). Revista Latinoamericana de Química 30(3):98-102.

Franco, A.S.L., P.A. Jiménez, L.C. Luna, and R. Figueroa-Brito. 2006. Efecto tóxico de semillas de cuatro variedades de Carica papaya (Caricaceae) en Spodoptera frugiperda (Lepidoptera: Noctuidae). Folia Entomológica Mexicana 45:171-177.

Gutiérrez-García, S.C., J. Sánchez-Escudero, J.F. Pérez-Domínguez, A. Carballo-Carballo, D. Bergvinson, and M.M. Aguilera-Peña. 2010. Efecto del nim en el daño ocasionado por el gusano cogollero Spodoptera frugiperda (Smith) (Lepidoptera: Noctuidae) en tres variables agronómicas de maíz resistente y susceptible. Acta Zoológica Mexicana (n. s.) 26:1-16.

Jactel, H., J. Petit, M.L. Desprez-Loustau, S. Delzon, D. Piou, A. Battist, and J. Koricheva. 2012. Drought effects on damage by forest insects and pathogens: a meta-analysis. Global Change Biology 18:267-276.

Jahn, G.C., L.P. Almazan, and J.B. Pacia. 2005. Effect of nitrogen fertilizer on the intrinsic rate of increase of Hysteroneura setariae (Thomas) (Homoptera: Aphididae) on rice (Oryza sativa L.) Environmental Entomology 34:938-943.

Kumar, G.V.P., and H. Raheman. 2012. Identification of optimum combination of proportion of vermicompost in the soil based potting mix and pot volume for the production of paper pot seedlings of vegetables. Journal Plant Nutrition 35:1277-1289.
Lima, J.F.M., D.A. Grützmacher, S.U. Cunha, P.M. Porto, S.J.F. Martins, and O.G. Dalmazo. 2008. Action of natural insecticide in control Spodoptera frugiperda (J. E. Smith, 1797) (Lepidoptera: Noctuidae) in corn crop cultivated in low agroecosystem. Ciencia Rural 38:607-613.

López, L.A., S. B. Villar, B.W. López, M.A. Zamarripa, F.A. Turrent, R.E. Garrido, M.J. López, M.E. Betanzos, and G.R. Camas. 1999. Manual de diagnóstico-prescripción para el cultivo de maíz en el estado de Chiapas. Campo Experimental Centro de Chiapas (CECECH), Instituto Nacional de Investigaciones Forestales, Agrícolas y Pecuarias (INIFAP). Ocozocoautla de Espinosa, Chiapas, Publicación Especial No. 5, México. 292 pp.

Lu, Z.X., X.P. Yu, K.L. Heong, and C. Hu. 2007. Effects of nitrogen fertilizer on herbivores and its stimulation to major pests in rice. Rice Science 14:56-66.

Mahanil, S., J. Attajarusit, M.J. Stout, and P. Thipayong. 2008. Overexpression of tomato phenol oxidase increases resistance to the common cutworm. Plant Science 174:456-466.

Méndez-Bautista, J., F. Fernández-Luqueño, F. López-Valdez, R. Mendoza-Cristino, J.A. Montes-Molina, F. A. Gutiérrez-Miceli, and L. Dendooven. 2009. Effect of pest controlling neem (Azadirachta indica A. Juss) and mataraton (Gliricidia sepium Jacquin) leaf extracts on emission of green house gases and inorganic$\mathrm{N}$ content in urea-amended soil. Chemosphere 76:293-299.

Mihn, J. 1984. Técnicas eficientes para la crianza masiva e infestación de insectos, en la selección de las plantas hospederas para la resistencia al gusano cogollero (Spodoptera frugiperda). Centro Internacional para el Mejoramiento del Maíz y Trigo (CIMMYT). México. Folleto técnico. 16 pp.

Moeser, J., and S. Vidal. 2004. Response of larvae of invasive maize pest Diabrotica virgifera virgifera (Coleoptera: Chrysomelidae) to carbon/nitrogen ratio and phytosterol content of European maize varieties. Journal of Economic Entomology 97:1335-1341.

Montes-Molina, J.A., M.L. Luna-Guido, N. EspinozaPaz, B. Govaerts, F.A. Gutiérrez-Miceli, and L. 
Dendooven. 2008. Are extracts of neem (Azadirachta indica A. Juss. (L.)) and Gliricidia sepium (Jacquin) an alternative to control pests on maize (Zea mays L.). Crop Protection 27:763-774.

Morales, H., I. Perfecto, and B. Ferguson. 2001. Traditional fertilization and its effect on corn insect populations in the Guatemalan highlands. Agriculture Ecosystems \& Environment 84:145-155.

Nevo, E., and M. Coll. 2001. Effects of nitrogen fertilization on Aphis gossypii (Homoptera: Aphididae): variation in size, color, and reproduction. Journal of Economic Entomology 94:27-32.

Nicholls, C.I., and M.A. Altieri. 2008. Suelos saludables, plantas saludables: la evidencia agroecológica. LEISA Revista de Agroecología 24(2): 6-8.

Pérez G., R. Padrón, Soto R., and Bertsch F. 1997. Efecto de tres plaguicidas naturales derivados del nim sobre el combate de plagas en col y maíz en el campo, y en Vigna unguiculata en almacenamiento. Agronomía Costarricense 21:259-266.

Pérez-Gutiérrez, S., M.A. Zavala-Sánchez, M.M. González-Chávez, N.C. Cárdenas-Ortega, and M.A. Ramos-López. 2011. Bioactivity of Carica papaya (Caricaceae) against Spodoptera frugiperda (Lepidoptera: Noctuidae). Molecules 16:7502-7509.

Phelan, P.L., J.F. Mason, and B.R. Stinner. 1995. Soil-fertility management and host preference by European corn borer, Ostrinia nubilalis (Hubner), on Zea mays L.: comparison of organic and conventional chemical farming. Agriculture Ecosystems \& Environment 56:1-8.

Pretty, J.N. 1997. Regenerating Agriculture: Policies and practices for sustainability and self-reliance. Earth scan Pub. Ltd., London, UK. 296 pp.

Rao, K.R. 2003. Influence of host plant nutrition on the incidence of Spodoptera litura and Helicoverpa armigera on groundnut. Indian Journal of Entomology 63:381-387.

Ratnadass, A., P. Fernandes, J. Avelino, and R. Habib. 2012. Plant species diversity for sustainable management of crop pests and diseases in agroecosystems: an review. Agronomy for Sustainable Development 32:273-303.

Rusch, A., M. Valantin-Morison, J.P. Sarthou, and J. Roger-Estrade. 2013. Effects of crop management and landscape context on insect pest populations and crop damage. Agriculture, Ecosytstems and Environment 166(15):118-125.

SAGARPA - Secretaría de Agricultura, Ganadería, Desarrollo Rural, Pesca y Alimentación. 2011. Perspectivas de largo plazo para el sector agropecuario de México 2011-2020. Subsecretaria de fomento a los agronegocios. Available online at: http://www.sagarpa.gob.mx/agronegocios/ Documents/estudios_economicos/escenariobase/ perspectivalp_11-20.pdf (Website accessed: October 10, 2012).

Sinha, R.K., S. Agarwal, K. Chauhan, and D. Valani. 2010. The wonders of earthworms and its vermicompost in farm production: Charles Darwin's 'friends of farmers', with potential to replace destructive chemical fertilizers from agriculture. Agricultural Sciences 1(2):76-94.

USDA - United States Department of Agriculture. 2011. World Agricultural Supply and Demand Estimates (WASDE). Word Agriculture Outlook Board 501:1-38.

Van Dusen, D. 1988. Global perspectives on agroecology and sustainable agricultural systems. Proceedings of the Sixth International Scientific Conference of the International Federation of Organic Agriculture Movements (IFOAM). Santa Cruz, CA, USA. 431 pp.

Wang, J.J., J.H. Tsai, and T.K. Broschat. 2006. Effect of nitrogen fertilization of corn on the development, survivorship, fecundity and body weight of Peregrinus maidis (Hom., Delphacidae). Journal of Applied Entomology 130:20-25.

Yardim, E.N., N.Q. Arancon, C.A. Edwards, T.J. Oliver, and R.J. Byrne. 2006. Suppression of tomato hornworm (Manduca quinquemaculata) and cucumber beetles (Acalymma vittatum and Diabotrica undecimpunctata) populations and damage by vermicomposts. Pedobiologia 50:23-29. 
